\title{
Flood risk assessment and management in Slovakia
}

\author{
M. Zeleňáková \\ Institute of Building and Environmental Engineering, \\ Technical University of Košice, Slovakia
}

\begin{abstract}
In recent years, the growth of population and the diffusion of settlements over flood vulnerable areas have increased the impact of floods worldwide. Natural disasters such as floods have constituted a major problem in many countries worldwide. Floods have caused immense economic and social losses, mainly as a result of unplanned urbanization, uncontrolled population density and not strictly inspected construction by authorities. Flood damages that have arisen on watercourses and hydraulic structures on the territory of the Slovak Republic have been huge. The most affected area is the eastern part of Slovakia, where the most complex situation is in the Laborec, Topla, Ondava, Torysa, Latorica and Hornád river basins in the recent years, mainly in 2010. This contribution presents flood risk assessment and management in these territories.

Keywords: flood risk assessment, flood risk management, directive 2007/60/EC.
\end{abstract}

\section{Introduction}

A new comprehensive approach on flood risk assessment and management on a European level has been triggered, especially after the large-scale flooding of 2002 in central Europe, with an estimated damage of 16.5 billion US\$ (2002: 1 US\$ $=1 €)$. The European Commission issued a Communication about flood risk management [1] in 2004. This initiative was followed by the adoption by the European parliament and the council of Directive 2007/60/EC on the Assessment and Management of Flood Risks [2] on 23 October 2007. The purpose of Directive 2007/60/EC [2] is to establish a framework for the assessment and management of flood risks, aiming at the reduction of the adverse consequences 
for human health, the environment, cultural heritage and economic activity associated with floods in the Community.

The Directive is based on the principle of the so-called 'hazard cycle' (Van Alphen et al. [3]). This means that a comprehensive risk management approach consists of a combination of prevention, preparation, response and recovery. Preventive measures reduce the probability of flooding of assets by spatial planning and construction and maintenance of flood protection works, like embankments. Preparation, response and recovery reduce the consequences when preventive measures fail. Preparation includes emergency planning and early warning. Response includes disaster management, crisis communication and evacuation. Recovery includes rebuilding of damaged assets and payment for financial losses by insurance companies.

\section{Materials and methods}

Floods, including flash floods, storm surges, snowmelt floods, ice jam and mud flows, are naturally occurring hazards that provide essential elements to the biodiversity and sustainability of ecosystems and many human activities. Flood risk is according to Directive 2007/60/EC [2] defined as a combination of the probability of a flood event and of the potential adverse consequences to human health, the environment, cultural heritage and economic activity associated with a flood event.

According to 2007/60/EC [2] EU Member States shall complete the preliminary flood risk assessment by 22 December 2011. Based on available or readily derivable information, such as records and studies on long term developments, in particular impacts of climate change on the occurrence of floods, a preliminary flood risk assessment shall be undertaken to provide an assessment of potential risks. The assessment shall include at least the following:

- maps of the river basin district at the appropriate scale including the borders of the river basins, sub-basins showing topography and land use;

- a description of the floods which have occurred in the past and which had significant adverse impacts and for which the likelihood of similar future events is still relevant, including their flood extent and conveyance routes and an assessment of the adverse impacts they have entailed;

- a description of the significant floods which have occurred in the past, where significant adverse consequences of similar future events might be envisaged;

- an assessment of the potential adverse consequences of future floods, taking into account as far as possible issues such as the topography, the position of watercourses and their general hydrological and geomorphological characteristics, including floodplains as natural retention areas, the effectiveness of existing man-made flood defence infrastructures, the position of populated areas, areas of economic activity and long-term developments including impacts of climate change on the occurrence of floods. 
The preliminary flood risk assessment will be used to identify areas which need to be considered in more detail through mapping and potentially the preparation of flood risk management plans [4]. In order to assess flood risk it is necessary to identify both the probability and consequences of flooding.

EU Member States shall prepare flood hazard maps and flood risk maps by 22 December 2013. Flood risk maps shall show the potential adverse consequences associated with flood scenarios. Flood hazard maps shall cover the geographical areas which could be flooded according to the following scenarios:

- floods with a low probability, or extreme event scenarios;

- floods with a medium probability (likely return period $\geq 100$ years);

- $\quad$ floods with a high probability, where appropriate.

For each scenario the following elements shall be shown:

- the flood extent;

- water depths or water level, as appropriate;

- where appropriate, the flow velocity or the relevant water flow.

Flood risk maps shall show the potential adverse consequences associated with flood scenarios and expressed in terms of the following:

- the indicative number of inhabitants potentially affected;

- type of economic activity of the area potentially affected;

- installations concerning integrated pollution prevention and control which might cause accidental pollution in case of flooding and potentially affected protected areas;

- $\quad$ other useful information such as the indication of areas where floods with a high content of transported sediments and debris floods can occur and information on other significant sources of pollution.

The Exchange Circle on Flood Mapping (EXCIMAP) has made an inventory of flood mapping practices in Europe. This inventory has resulted in a 'Handbook on Good Practices for flood mapping in Europe' and an 'Atlas of Flood maps containing examples from 19 European countries, Japan and USA' [5].

On the basis of the maps Member States shall establish flood risk management plans by 22 December 2015. Flood risk management plans shall take into account relevant aspects such as costs and benefits, flood extent and flood conveyance routes and areas which have the potential to retain flood water, such as natural floodplains, the environmental objectives of Directive 2000/60/EC, soil and water management, spatial planning, land use, nature conservation, navigation and port infrastructure. The purpose of the flood risk management plans is to identify means of reducing the impacts of flooding.

\section{Results}

In the last decade, Slovakia is increasingly affected by floods. These floods, especially in May and June 2010, have been recorded in substantial material damage and there are exceptional cases of loss of human life. Floods constantly point to the fact that the society is very vulnerable to flooding. In the last 13 
years have caused floods in Slovakia, the loss of at the least 56 lives and affected more than 2500 villages and towns; only in the year 2010 the floods damages were calculated to 695,1 million $€$. Scope and extremity of flood episodes point to the need to build a comprehensive proposal eventually completion of flood protection measures in potential flood areas. Proposal for flood protection measures are fully devoted to the management of flood risk (Šlezingr [6]).

Flood risk analysis provides a rational basis for prioritizing resources and management actions. Risk analysis can take many forms, from informal methods of risk ranking and risk matrices to fully quantified analysis (Hall [7]).

The assessed watershed (Figure 1) is situated in the eastern part of Slovakia country.
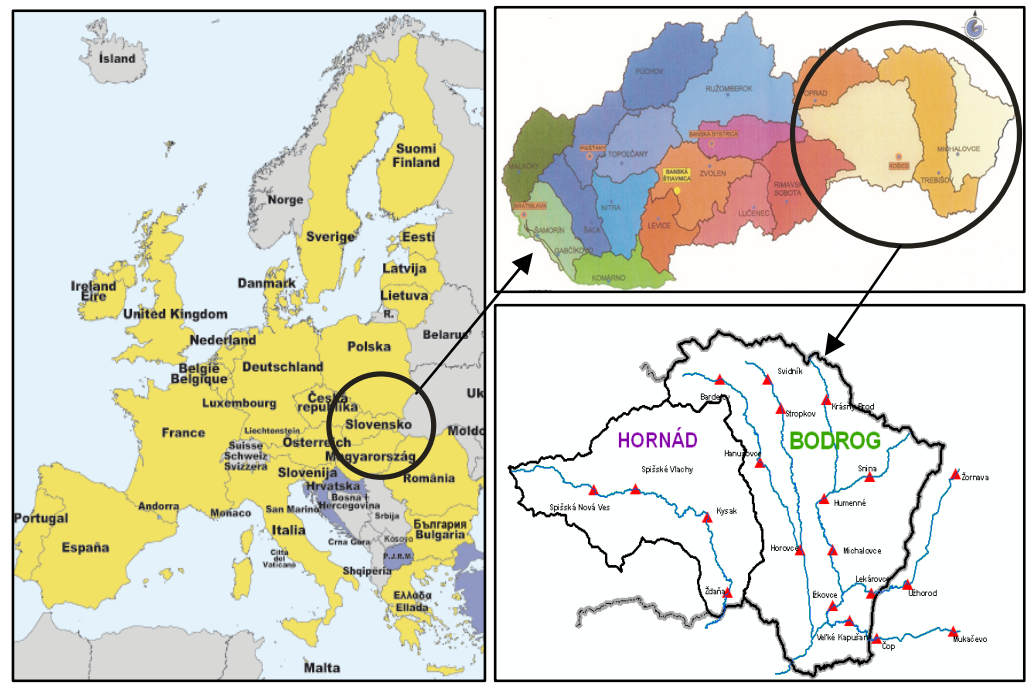

Figure 1: $\quad$ Assessed watershed.

Preliminary flood risk assessment shall include, as was mentioned, a description of the floods which have occurred in the past and which had significant adverse impacts and for which the likelihood of similar future events is still relevant. Table 1 presents the number of flood grades occurrence (I. or II. or III.) in river stations in ten years period (2001-2010). The occurrence of flood grades is determined for each river station according the height of water level in the river (Zeleňáková [8]).

The results from preliminary flood risk assessment in the assessed watersheds show that flood risks are in the lower parts of the river watershed where its tributaries flow into and the highest flood risks are in the cities Bardejov, Michalovce and Humenné. 
Table 1: $\quad$ Number of flood days at river stations.

\begin{tabular}{|c|c|c|c|c|c|}
\hline Watershed & River & $\begin{array}{c}\text { River } \\
\text { station }\end{array}$ & $\begin{array}{c}\text { Number of } \\
\text { I. FG }\end{array}$ & $\begin{array}{c}\text { Number of } \\
\text { II. FG }\end{array}$ & $\begin{array}{c}\text { Number of } \\
\text { III. FG }\end{array}$ \\
\hline \multirow{4}{*}{ تِّ } & \multirow{4}{*}{ Hornád } & Ždan̆a & 309 & 22 & 5 \\
\hline & & Kysak & 146 & 15 & 5 \\
\hline & & Sp.Vlachy & 14 & 2 & 1 \\
\hline & & S.N.Ves & 0 & 0 & 0 \\
\hline \multirow{16}{*}{ 象 } & Cirocha & Snina & 0 & 0 & 0 \\
\hline & \multirow{4}{*}{ Laborec } & Ižkovce & 6 & 9 & 1 \\
\hline & & Michalovce & 11 & 1 & 0 \\
\hline & & Humenné & 7 & 2 & 0 \\
\hline & & K. Brod & 3 & 0 & 1 \\
\hline & \multirow{3}{*}{ Latorica } & V.Kapušany & 344 & 206 & 22 \\
\hline & & $\check{C}$ op & 230 & 345 & 189 \\
\hline & & Mukačevo & 0 & 0 & 0 \\
\hline & \multirow{3}{*}{ Ondava } & Horovce & 5 & 8 & 3 \\
\hline & & Stropkov & 6 & 9 & 2 \\
\hline & & Svidnik & 2 & 1 & 0 \\
\hline & \multirow{2}{*}{ Topl'a } & Hanušovce & 14 & 11 & 5 \\
\hline & & Bardejov & 11 & 2 & 1 \\
\hline & \multirow{3}{*}{ Uh } & Lekárovce & 9 & 5 & 3 \\
\hline & & Užhorod & 0 & 0 & 0 \\
\hline & & Žornava & 8 & 1 & 2 \\
\hline
\end{tabular}

The following assessment of the potential likelihood of future floods has been taking into account as far as possible issues such as the general hydrological and geo-morphological characteristics - specifically the annual rainfall and soil types. The model area was represented by soil types and average annual precipitation divided into five classes - see Table 2 .

Table 2: $\quad$ Categories for soil types and annual precipitation.

\begin{tabular}{|c|c|c|c|}
\hline Soil types & $\begin{array}{c}\text { Content of clay } \\
\text { particle } \\
(\mathbf{\%})\end{array}$ & Category & $\begin{array}{c}\text { Annual } \\
\text { precipitation } \\
\text { (mm) }\end{array}$ \\
\hline predominantly sandy & $1-10$ & $\mathbf{1}$ & $0-600$ \\
\hline mostly loam-sandy & $10-30$ & $\mathbf{2}$ & $600-800$ \\
\hline predominantly loam & $30-45$ & $\mathbf{3}$ & $800-1200$ \\
\hline mostly clay-loam & $45-60$ & $\mathbf{4}$ & $1200-2000$ \\
\hline clay & more than 60 & $\mathbf{5}$ & more than 2000 \\
\hline
\end{tabular}


The evaluation was carried out using the matrix method of risk analysis. An example of such an acceptance of flood risk assessment risk matrix is shown in Table 3 .

Table 3: $\quad$ Flood risk assessment matrix.

\begin{tabular}{|c|c|c|c|c|c|}
\hline \multirow{2}{*}{$\begin{array}{c}\text { Annual } \\
\text { prec. }\end{array}$} & \multicolumn{5}{|c|}{ Soil types } \\
\hline & 1 & 2 & 3 & 4 & 5 \\
\hline 1 & acceptable & acceptable & acceptable & moderate & moderate \\
\hline 2 & acceptable & acceptable & moderate & moderate & undesirable \\
\hline 3 & acceptable & moderate & moderate & undesirable & undesirable \\
\hline 4 & moderate & moderate & undesirable & undesirable & unaccept. \\
\hline 5 & moderate & undesirable & undesirable & unaccept. & unaccept. \\
\hline
\end{tabular}

A graphic presentation of the results of the flood risk assessment is carried out using the ArcGIS software (Gaňová [9]). For each river basin the acceptability of the risks is indicated by a colour matrix of risk acceptance based on risk assessment - see Figure 2.

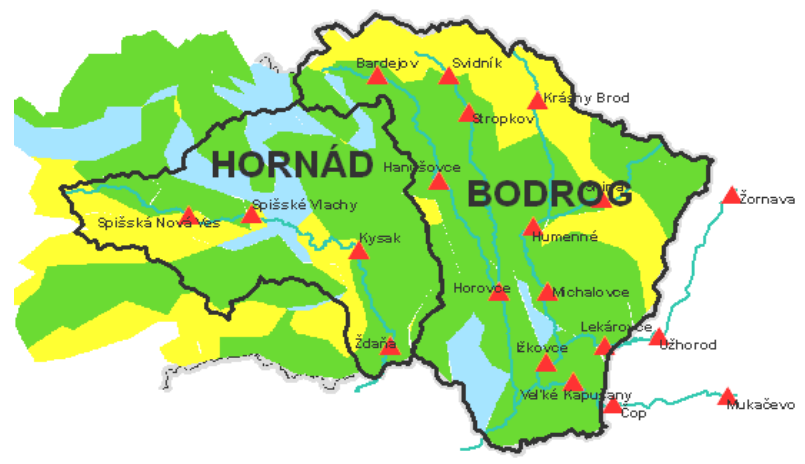

Legend

Figure 2: $\quad$ Map of flood hazard areas.

The flood risk assessment showed that almost the whole of eastern Slovakia has a moderate flood risk, which means that there is a need for constant monitoring of the situation. In the northern part of eastern Slovakia - Bardejov, Svidník, Stropkov, Snina and Humenné there is undesirable flood risk as well as in Hornád basin - especially in Ždaňa, Kysak, Spišská Nová Ves. In these areas it is necessary to design flood protective measures to reduce the risk of flooding. Only in the minimum of the assessed area is the flood risk acceptable.

Flood risk maps show the potential adverse consequences associated with flood scenarios, mostly with a medium probability (likely return period $=100$ years). In Figure 3 a flood hazard map for Bardejov City is shown (Olbricht [10]). 


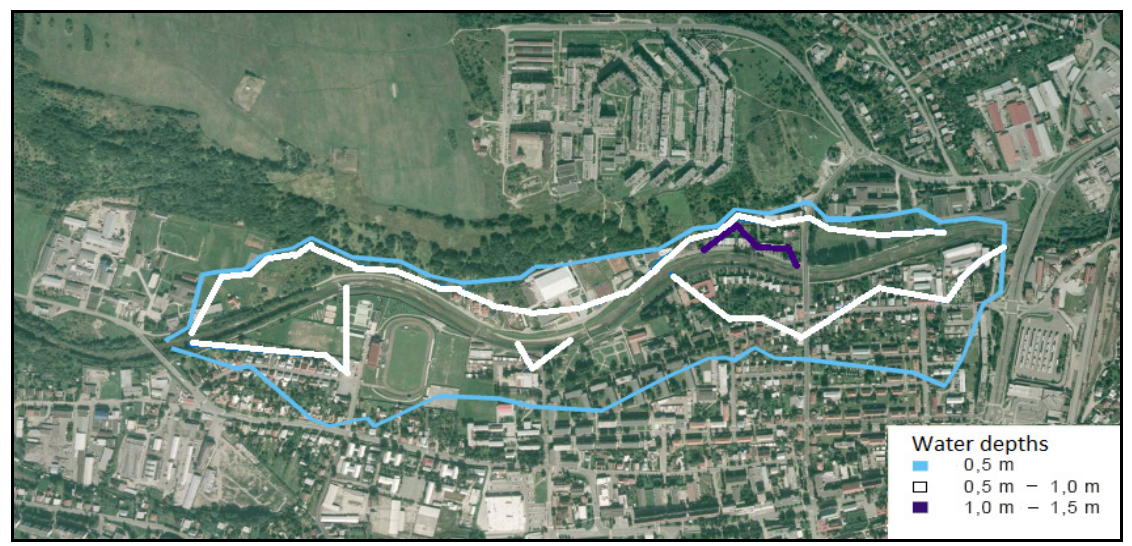

Figure 3: $\quad$ Flood hazard map.

The flood hazard map shows the flood extent - water depths or water level, as appropriate. The flood risk map shows the potential adverse consequences associated with flood scenarios and expressed in terms of the type of economic activity of the areas potentially affected.

Flood risk management includes measures to reduce potential adverse effects of floods. There are three major ways that societies have attempted to manage floods:

- Structural measures: land drainage modification, reservoirs, embankments, polders, etc.;

- Non-structural measures: regulations, flood defense, flood insurance;

- Do nothing: learn to live with floods.

Flood risk management plans shall address all aspects of flood risk management focusing on prevention, protection, preparedness, including flood forecasts and early warning systems and taking into account the characteristics of the particular river basin or sub-basin. Flood risk management plans may also include the promotion of sustainable land use practices, improvement of water retention as well as the controlled flooding of certain areas in the case of a flood event.

\section{Discussion}

Finally, the main recommendations for flood risk assessment and management (modified according to Simonovic [11]) are:

- to fully exploit basic and advanced information technologies to improve environmental representation, flood characterization and prediction, and to foster intersectoral communication and collaboration;

- to continue introduction of flood risk and impact assessment with any new development proposal;

- to continue advancement of integrated floodplain management principles and practices, including a more fully balanced approach of structural and nonstructural flood protection measures; 
- $\quad$ to proceed with the development of variable procedures to more effectively manage the flood risk within various sectors of society;

- to enhance awareness of local flood management capacities and the need for affected groups and individuals to assume their share of the risk;

- to continue advancement of strategies to involve a broader range of groups and individuals in decision-making processes based on common, basinwide visions; and

- to continue exchange of information related to flood management through regional and international initiatives and meetings.

\section{Conclusions}

During the last decades, floods in Europe have become a growing topic of concern for citizens, authorities, insurance companies and policy makers.

Flood extent, depth and consequences depend on the magnitude of the flood event, represented by the extreme water level in the river, lake or sea from which the flood originates. This extreme water level has a certain probability of occurrence.

Geographic approach to flood risk assessment provides a descriptive presentation of the results obtained. Created thematic maps show the suitability of using ArcGIS software wherever it is necessary to make quick and effective decisions in emergency relief efforts for flood protection needs. People must learn to live with floods in the future. The value of the property threatening flooding is increasing. Therefore, attention must focus on the whole society to prevent and protect itself from big water to reduce or damage minimized.

Floods can anywhere and anytime have disastrous consequences, so it is desperately important to place emphasis on early warning and adequate protection against flooding.

The appropriate flood risk mitigation investment, and the redirection of resources into flood disaster prevention, offers significant economic benefits, as well as reduction in loss of life and property, improvements in welfare and social stability.

Flood risk reduction is an integral part of river basin management and which aims to maximize the resultant economic and social welfare in an equitable manner without compromising the sustainability of vital systems.

This paper presents the application of flood risk assessment and management under the conditions of the eastern part of Slovakia.

\section{Acknowledgements}

The Centre was supported by the Slovak Research and Development Agency under the contract No. SUSPP-0007-09. Thanks are also made for the support of the APVV project SK-PL-0022-09. 


\section{References}

[1] Flood risk management: flood prevention, protection and mitigation. COM (2004/472/final). Brussels: Council of European Communities, 2004.

[2] Directive on the assessment and management of flood risks (2007/60/EC). Official J, L288, pp. 27-34. Brussels: The European Parliament and the Council of the European Union, 2007.

[3] Van Alphen, J., Martini, F., Loat, R., Slomp, R., Passchier, R., Flood risk mapping in Europe, experiences and best practices. J Flood Risk Manage, 2, pp. 285-292, 2009.

[4] Floodsite Potential Support for Preliminary Flood Risk Assessment. http://www.floodsite.net/html/flood risk assesment.htm

[5] Handbook on good practices for flood mapping in Europe Handbook on good practices for flood mapping in Europe European exchange circle on flood mapping (EXCIIMAP), 2007. http://ec.europa.eu/environment/water/ flood_risk/flood_atlas/pdf/handbook_goodpractice.pdf

[6] Šlezingr, M, Reasons of the revitalization of watercourses. Selected Scientific Papers. Journal of Civil Engineering, 4 (1), pp. 69-80, 2009.

[7] Hall, J., Editorial: Journal of Flood Risk Management. J Flood Risk Manage, 3, pp. 1-2, 2010.

[8] Zeleňáková, M., Flood risk assessment. Thesis. Košice: Technical University of Košice, Faculty of Civil Engineering, 2009.

[9] Gaňová, L., Hodnotenie a manažment povodňového rizika. Diploma work. Košice: Technical University of Košice, Faculty of Civil Engineering, 2010.

[10] Olbricht, V., Hodnotenie rizík v záplavových územiach. Thesis. Košice: Technical University of Košice, Faculty of Civil Engineering, 2009.

[11] Simonovic, S. P., Managing flood risk, reliability and vulnerability. J Flood Risk Manage, 2, pp. 230-231, 2009. 